\title{
The Effect of Quality Management on the Performance in Aviation Industry in Nigeria
}

\author{
Adesoji Kayode \\ Department of Business Administration, Faculty of Management and Social Science, Nile University, Abuja, Nigeria \\ Email address: \\ 201348020@nileuniversity.edu.ng \\ To cite this article: \\ Adesoji Kayode.The Effect of Quality Management on the Performance in Aviation Industry in Nigeria. Science Journal of Business and \\ Management. Vol. 9, No. 3, 2021, pp. 203-208. doi: 10.11648/j.sjbm.20210903.17
}

Received: July 9, 2021; Accepted: July 20, 2021; Published: July 27, 2021

\begin{abstract}
The increasing demand by clients for better quality of transportation services in Nigeria has encouraged many companies especially in the aviation industry to provide quality services in order to grow in the marketplace. To meet this feat, the aviation industry in Nigeria has invested substantial resources in adapting and implementing quality management practices in their operations. The objective of this study is to evaluate the effect of quality management practices on the operational performance in Aviation industry in Nigeria. However, the specific objectives are to determine the relationship and the effect of quality management practices and operational performance in aviation sector. This study design is a descriptive research survey design which was analyzed using correlation and multiple regression analysis to evaluate the relation and the effect of quality management practices on operational performance. These analyses were carried out using statistical data for social scientist (SPSS v.22). The study reveals that there are positive and statistically significant relationship between quality management practices and operational performance at $5 \%$ level of significance. The study also concludes that quality management practices have significant positive effect on operational performance of aviation industry in Nigeria. The study therefore recommends that quality management practices should be effectively managed in the industry because each practice improves different aspects of firms' operational performance.
\end{abstract}

Keywords: Quality Management, Leadership, Customer Focus, Strategic Quality Planning, Performance, Operational Performance

\section{Introduction}

In recent years, the importance of the urban transport sector in Nigeria cannot be overemphasized as the increase in ruralurban migration continues to grow. More than two-third of the productive class such as workers, entrepreneurs, traders and students among others are involved in market-oriented services that involves transportation [6]. The purpose of corporate activities is to improve performance either financial or nonfinancial. Given that the transport sector is one of the most critical sectors in Nigeria, the need to increase its non-financial performance or operational performance towards achieving effectiveness, reliability and users' satisfaction is evident [2]. Therefore, the concern for improving operational performance among others has favoured the development of quality management practices or initiatives.

Quality management (QM) practices have been widely accepted as the management model that provides a competitive advantage through quality. Kumar, Maiti and Gunasekaran, (2018) declared that QM is one of the most popular and most often recommended approaches to help companies improve efficiency and competitiveness. Increasing demand by clients and customers for better quality of transportation services in market environment has encouraged many companies especially in the aviation industry to provide quality services in order to compete, survive and grow in the marketplace successfully. To meet the challenge of this global competition, many air transportation services providers in Nigeria have invested substantial resources in adapting and implementing total quality management practices in their operations. In this regard therefore, the need for the evaluation of the effect of quality management practices in the aviation industry in Nigeria on operational performance with focus on Federal Airports Authority of Nigeria (FAAN) and Nigerian Civil Aviation Authority (NCAA), Abuja. 


\subsection{Statement of the Problem}

The impacts of quality management (QM) practices on performance have been the subject of constant interests and challenges among researchers in the field of quality assurance and management [1]. Several empirical studies have attempted to investigate $\mathrm{QM}$ practice performance relationships in different contexts. However, other studies such as $[9,13]$ argued that it is very difficult to establish relationships between the dimensions of $\mathrm{QM}$ and the performance of companies. In other perspectives, studies such as $[1,2]$ present a very negative picture of QM practices implementation benefits while studies such as [9] and [12] argue that QM practices have positive impacts on organizational performance.

The existing body of literatures on quality management practices and organizational performance present several inconsistent results as to the relationship that exists among them. It is against this backdrop that this study centers on forming opinion on the effect of quality management practices on operational performance of the aviation industry in Nigeria.

\subsection{Objectives of the Study}

The objective of this study is to evaluate the effect of quality management practices on the operational performance of transport sector in Nigeria. However, the specific objectives of this study are:

To determine the effects of leadership commitment practice on operational performance in aviation industry in Nigeria.

To determine the effects of customer focus practice on operational performance in aviation industry in Nigeria.

To determine the effects of strategic quality planning practice on operational performance in aviation industry in Nigeria.

\subsection{Research Questions}

The research questions that this study seeks to answer are:

What is the effect of leadership on operational performance in aviation industry in Nigeria?

What is the effect of customer focus practice on operational performance in aviation industry in Nigeria?

What is the effect of strategic quality planning practice on operational performance in aviation industry in Nigeria?

Hypotheses:

The statements of hypotheses of the study based on the research framework are presented below:

$H_{01}$ : Effective leadership practices have no significant effect on operational performance of aviation industry in Nigeria.

$H_{02}$ : Customer focus practices have no significant effect on operational performance of aviation industry in Nigeria.

$H_{03}$ : Strategic quality planning practices have no significant effect on operational performance of aviation industry in Nigeria.

\section{Literature Review}

\subsection{Quality Management}

Quality management is a plan to produce and deliver services or commodities, which are consistent with customers' needs or requirements by faster, better, safer, cheaper, easier processing than competitors with the involvement of all employees under top management leadership [13]. Quality management is a culture of an organization committed to customer loyalty/satisfaction through continuous improvement. This culture varies from one country to another on one hand and between different industries on the other hand, but has certain essential principles which can be implemented to secure improved market share, better profits and reduced costs. Major common practices of these quality improvement plans include top management commitment or leadership, knowledge management, process management, training and education, supplier quality management, customer focus and strategic quality planning [14]. This study therefore adopts the quality management practices as articulated by $[14,16,17]$ because it represents the essence of quality management in the aviation industry in Nigeria.

\subsection{Performance}

According to [18], performance is the level to which an organization achieves its strategic objectives and goals, as well as indicator to evaluate the organization's overall competiveness. Organizational performance has measured by using both financial (including return on investment, return on asset, return on equity, market share, profit margin on sales, the growth of ROI, the growth of sales, and the growth of market share) operational performance including cost of production, flexibility, time and quality [4]. This conceptualization allows the researcher to obtain a holistic picture regarding how transport organizations reflect on their operational and organizational performance where the former involves activities taken during the implementation of a quality management initiatives deals with measures in improving quality of service, cost and waste reduction while the latter deals with financial and non-financial measures such as profitability, customer satisfaction, research and development etc [3-5].

However, this study focused on operational performance. Companies operating in different environment have different forms of operational performances.

\subsection{Research Framework}

The quality management practice considered in this study are leadership, knowledge management and process management which serve as the independent variables of the study while operational performance served as the dependent variable. The research framework is therefore presented in the figure below: 


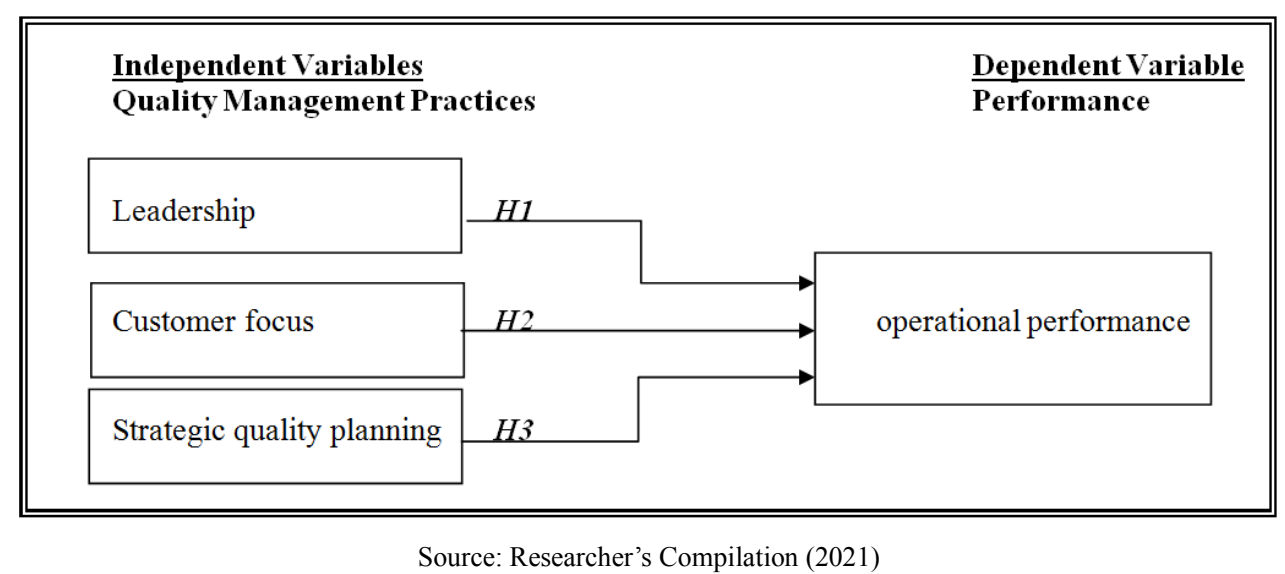

Figure 1. Research Framework of the Study.

\subsection{Strategic Quality Planning $\mathrm{H} 3$}

Leadership: Leadership in quality management system considers organization as a system; support subordinates' development; establish a multi-channel communication network among the managers, employees and clients/customers; involves employee participation in decision-making and use information effectively and efficiently.

Customer Focus: In quality management practice, industries focus on serving both the external and internal customers by knowing their expectations and requirements followed by offering them the products/services, accordingly. This is done by the aid of successful customer focus efforts, production may be arranged with respect to the customers' needs, expectations and complaints. When customer expectations are met, their satisfaction will be increased, and the firm's patronage will be improved.

Strategic Quality Planning: In quality management practices, strategic quality planning involves the mission, vision and core values of the firms which are formed with quality concept in mind; employees' interest at heart and the likely consequences of the plan to the environment prior to the production. This ensures acceptance, reinforcement and support of strategic quality plans by the employees and improve social responsibility of the industry.

\section{Methodology}

This study used descriptive research survey design because it was suitable for the study as the study sought to evaluate the effect quality management on operational performance. The means of data collection was via both physical and virtual-based questionnaires administered to randomly selected management staff of the Federal Airports Authority of Nigeria (FAAN) and Nigerian Civil Aviation Authority (NCAA). Respondents are management staffs who have the best knowledge about the operation and quality management in the aviation industry. So, it was decided to choose managers who are relevant to the current study such as quality managers and production/operation managers.
A total of 50 respondents were selected for the survey therefore, 50 copies of questionnaire were distributed out of which 42 copies representing $84 \%$ were validly returned and confirmed suitable for the analysis. The estimation technique that is employed in this study in functional form, is expressed as:

$$
\begin{gathered}
\mathrm{OP}=f(\mathrm{TQT}) \\
\mathrm{OP}=f(1, \mathrm{cf}, \mathrm{sqp})
\end{gathered}
$$

In equation for, it is expressed as:

$$
\mathrm{OP}=\beta_{\mathrm{o}}+\beta_{1} 1+\beta_{2} \mathrm{cf}+\beta_{3} \mathrm{sqp}+\varepsilon
$$

(Where; OP= operational performance; $l=$ leadership; $c f$ = customer focus; $s q p=$ strategic quality planning, $\beta_{o}=$ intercept, $\beta_{1}, \beta_{2}$, and $\beta_{3,=}$ slopes for $l, k m$, and sqp. $\varepsilon=$ error of estimate).

The validity of the adapted instrument from [14] was further established through content, face and constructs validity. However, the reliability test of each of the constructs was carried out using Cronbach's Alpha and the average results show that the data were normally distributed and the scale reliability was 0.85 on a scale of 1 . The hypotheses of the study were tested using multiple regression analysis; this is to allow for the evaluation of the extent of the effect of quality management practices on operational performance. These analyses were carried out using statistical data for social scientist (SPSS v.22).

For the purpose of research consideration, ethical issues were upheld. The study ensures that respondents stayed anonymous with confidentiality of all information provided by them. The study utilized research assistants to ensure prompt responses that were devoid of influence and none repetition of participants.

\section{Results and Discussion}

\subsection{Regression Analysis}

The results of the hypotheses testing using multiple regression analysis are presented in Table 1: 
Table 1. Model Analysis for Hypotheses.

\begin{tabular}{lllll}
\hline Variables & Coefficient & Std. Error & t stat & p-value \\
\hline Constant (OP) & 4.072 & 2.721 & 0.625 & 0.000 \\
Leadership $(l)$ & 0.352 & 1.489 & 2.434 & $0.019^{*}$ \\
Customer focus $(f s)$ & 0.178 & 0.332 & 0.637 & $0.000^{* *}$ \\
Strategic quality planning (sqp) & 0.445 & 0.342 & 0.667 & $0.012^{*}$ \\
R & 0.631 & Variables & & Values \\
R-squared & 0.649 & S. E of regression & & 3.95495 \\
Adj. R-squared & 0.445 & Df & & 41 \\
No of Obs & 42 & f- stat & & 2.794 \\
\hline
\end{tabular}

$* *$ level of significance $=1 \%$; $*$ level of significance $=5 \%$

Source: SPSS output, 2021

The result presented above reveals that all the variables; that is, quality management practices have significant positive effect on operational performance at 5\% significant level in both long and short-run $(p=0.000$; f-stat $=2.794)$. It further indicates that $\mathrm{R}$ value of 0.649 reveals that the quality management practices have a strong relationship with the operational performance. Also, the adjusted $\mathrm{R}$ square value of 0.445 reveals that $44.5 \%$ of the variations in the operational performance are explained by variations in the quality management practices.

Hypothesis One:

$H_{01}$ : Effective leadership practices have no significant effect on operational performance of aviation industry in Nigeria.

The $p$-value of 0.001 (i.e $p<0.05$ ) indicates that the null hypothesis should be rejected which indicates that effective leadership practices have significant effect on operational performance of aviation industry in Nigeria. Also, a unit increase in effective leadership will lead to increase in operational performance by $0.35 \%$. This finding is consistent with the expected results of the related studies reviewed $[7,8,11]$.

Hypothesis Two:

$H_{02}$ : Customer focus practices have no significant effect on operational performance of aviation industry in Nigeria.

The $\mathrm{p}$-value of 0.000 (i.e $\mathrm{p}<0.05$ ) indicates that the null hypothesis should be rejected which indicates that customer focus practices have significant effect on operational performance of aviation industry in Nigeria. Also, a unit increase in customer focus practice will lead to increase in operational performance by $0.18 \%$. This finding is consistent with the expected results of the related studies reviewed $[2,7,11]$.

Hypothesis Three:

$H_{03}$ : Strategic quality planning practices have no significant effect on operational performance of aviation industry in Nigeria.

The $p$-value of 0.012 (i.e $p<0.05$ ) indicates that the null hypothesis should be rejected which indicates that strategic quality planning practices have significant effect on operational performance of aviation industry in Nigeria. Also, a unit increase in process management practice will lead to increase in operational performance by $0.445 \%$. This finding is consistent with the expected results of the related studies reviewed $[7,15]$.

\subsection{Discussion}

The effective leadership practices have significant effect on operational performance of aviation industry in Nigeria as revealed by this study. This finding is consistent with the expected results of the related studies reviewed. This shows that the finding of this study is supported by other studies [7, $11,8]$ which also showed a positive effect of effective leadership on organizational performance.

Secondly, customer focus practices have significant effect on operational performance of aviation industry in Nigeria. This finding is consistent with the expected results of the related studies reviewed. This shows that the finding of this study is supported by other studies $[2,7,11]$ which also showed a positive effect of customer focus on organizational performance.

Lastly, that strategic quality planning practices have significant effect on operational performance of aviation industry in Nigeria. This finding is consistent with the expected results of the related studies reviewed. This shows that the finding of this study is supported by other studies [8, 15] which also showed a positive effect of strategic quality planning on organizational performance.

\section{Conclusion and Recommendations}

\subsection{Conclusion}

In this study, it can be concluded that quality management practices improve operational performance measures in the aviation industry. All the three quality management practices explored showed a positive significant effect on the operational performance in the aviation industry. This indicates that the costs of operation in the industry are reduced, the quality of services is improved and the average time of delivery of the services has improved as a result of adequate deployment of quality management practices by the management. Finally, these operational models approach have contributed significantly to the organizational growth and development.

\subsection{Recommendations}

All aspects of quality management practices should be 
effectively managed in an organization because each factor in quality management practices improves different aspects of firm operational performance.

The collaboration that exists among the quality management factor sbrings about critical enhancement and improvements in the operational performances. Furthermore, firms need to improve employee involvement/skill through training and retraining.

Also, firms' structure should be improved and they should be more allocation of sufficient resources, both human and material resources, to institutionalize quality management successfully.

\subsection{Policy Implications}

This study reveals a significant and positive relationship between quality management and operational performance measures which shows the importance of each of these practices to improve operational performance and sustainability. The justification of quality management implementations may provide the managers with information on how to re-energize and motivate subordinates in these applications towards improving operational performance. The findings of this study can also be used for the organization who have already used quality management practices in the short run to assess the progress and to improve their organization's performance.

\subsection{Limitations}

Firstly, the study limits itself to operational performance as an aspect of organizational performance because they are conveniently measured using primary sources. This study largely depends on subjective measures performance which may not give accurate information to test the hypotheses because it came from the management staffs who are active players in protecting the corporate social interest of the organization. However, the study compared the top management in different units in the agency considered by using subjective measurements. Secondly, this study obtained perceived data about actual quality management practices and performance measures, but there spondents might have given desired data, which made their agency look good. Lastly, the agency considered was in the aviation industry which would raise concerns about generalization to transport sector, reliability, and validity of the study.

\section{References}

[1] Augustyn, M. M., Elshaer, I. A., \& Akamavi, R. K. (2019). Competing models of quality management and financial performance improvement. The Service Industries Journal, 129. https://doi.org/10.1080/02642069.2019.1601706

[2] Bashan, A., \& Armon, D. (2019). Quality management challenges in a dynamic reality of mergers, acquisitions and global expansion. International Journal of Quality \& Reliability Management, 36 (7), 1192-1211. https://doi.org/10.1108/ijqrm-06-2018-0161
[3] Basu, R., \& Bhola, P. (2016). Impact of quality management practices on performance stimulating growth. International Journal of Quality \& Reliability Management, 33 (8), 1179-1201. https://doi.org/10.1108/ijqrm-10-20150153

[4] Clegg, B., Gholami, R., \& Omurgonulsen, M. (2012). Quality management and performance: a comparison between the UK and Turkey. Production Planning \& Control, 24 (12), 1015-1031. https://doi.org/10.1080/09537287.2011.642486

[5] Ebrahimi, M., \& Sadeghi, M. (2013). Quality management and performance: An annotated review. International Journal of Production Research, 51 (18), 5625-5643. https://doi.org/10.1080/00207543.2013.793426

[6] Ishola, O. A., \& Olusoji, M. O. (2020). Service Sector Performance, Industry and Growth in Nigeria. International Journal of Service Science, Management, Engineering, and Technology, $11 \quad$ (1), 31-45. https://doi.org/10.4018/ijssmet.2020010103

[7] Iyer, A., Saranga, H., \& Seshadri, S. (2013). Effect of Quality Management Systems and Total Quality Management on Productivity Before and After: Empirical Evidence from the Indian Auto Component Industry. Production and Operations $\begin{array}{llll}\text { Management, } & 22 & \text { (2), }\end{array}$ https://doi.org/10.1111/poms. 12000

[8] Jiménez-Jiménez, D., Martinez-Costa, M., Martínez-Lorente, A. R., \& Rabeh, H. A. D. (2015). Total quality management performance in multinational companies. The TQM Journal, 27 (3), 328-340. https://doi.org/10.1108/tqm-01-2014-0002

[9] Kumar, P., Maiti, J., \& Gunasekaran, A. (2018). Impact of quality management systems on firm performance. International Journal of Quality \& Reliability Management, 35 (5), 1034-1059. https://doi.org/10.1108/ijqrm-02-20170030

[10] Mohammed, Sani. Abdullaho., Ummi Rahma Shehu, Bashir Mikail Usman, \& Alhassan Musa Gumawa. (2020). Relationship between total quality management and organizational performance: Empirical evidence from selected airlines in Nigeria Aviation Industry. Asian People Journal (APJ), 33 (1), $30-44$. https://doi.org/10.37231/apj.2020.3.1.128

[11] O'Neill, P., Sohal, A., \& Teng, C. W. (2016). Quality management approaches and their impact on firms' financial performance - An Australian study. International Journal of Production Economics, 171, 381-393. https://doi.org/10.1016/j.ijpe.2015.07.015

[12] Panuwatwanich, K., \& Nguyen, T. T. (2017). Influence of Total Quality Management on Performance of Vietnamese Construction Firms. Procedia Engineering, 182, 548-555. https://doi.org/10.1016/j.proeng.2017.03.151

[13] Patyal, V. S., \& Maddulety, K. (2015). Interrelationship between Total Quality Management and Six Sigma: A Review. Global Business Review, 16 (6), 1025-1060. https://doi.org/10.1177/0972150915597607

[14] Sadikoglu, E., \& Olcay, H. (2014). The Effects of Total Quality Management Practices on Performance and the Reasons of and the Barriers to TQM Practices in Turkey. Advances in Decision Sciences, 2014, 1-17. https://doi.org/10.1155/2014/537605 
[15] Swanepoel, T., van der Waldt, G., \&Steyn, E. (2015). A quality management model for community newspapers: the case of developing countries. Total Quality Management \& Business Excellence, 27 (9-10), 1191-1209. https://doi.org/10.1080/14783363.2015.1075875

[16] Sweis, R. J., Ismaeil, A. S., Amayreh, I., \& Al-Sayyed, N. (2019). The relationship Between Total Quality Management (TQM) implementation and organisation performance: evidence from the airlines companies in UAE. International Journal of Information, Business and Management, 11 (1), 64-85.
[17] Sweis, R. J., Sweis, N. J., \& Elhawa, N. A. (2019). Total quality management practices and their impact on performance: case study of Royal Jordanian Airlines. International Journal of Business Excellence, 17 (2), 245. https://doi.org/10.1504/ijbex.2019.10018698

[18] Tortorella, G., Giglio, R., Fogliatto, F. S., \& Sawhney, R. (2019). Mediating role of learning organization on the relationship between total quality management and operational performance in Brazilian manufacturers. Journal of Manufacturing Technology Management, 31 (3), 524-541. https://doi.org/10.1108/jmtm-05-2019-0200 